\title{
Early Erythropoietin for Preventing Red Blood Cell Transfusion in Preterm and/or Low Birth Weight Infants
}

\section{Cochrane Abstract}

Background: Low plasma levels of erythropoietin (EPO) in preterm infants provide a rationale for the use of EPO to prevent or treat anemia. Objectives: To assess the effectiveness and safety of early initiation of EPO in reducing red blood cell (RBC) transfusions in preterm and/or low birth weight infants. Search Methods: The Cochrane Central Register of Controlled Trials (The Cochrane Library), MEDLINE, EMBASE, $\mathrm{CINAHL}$, abstracts from scientific meetings published in $\mathrm{Pe}$ diatric Research and reference lists of identified trials and reviews were searched through July 2009. Selection Criteria: Randomized or quasi-randomized controlled trials of early ( $<8$ days of age) initiation of EPO treatment vs. placebo or no intervention in preterm and/or low birth weight neonates. Data Collection and Analysis: Data collection and analysis were accomplished using the methods of the Cochrane Neonatal Review Group. Main Results: Update includes 27 studies that enrolled 2,219 preterm infants. Early EPO reduced the risk of the 'use of one or more RBC transfusions' [typical RR; 0.80 (95\% Cl 0.75, 0.86); 16 studies, 1,825 infants] (fig. 1). Early EPO led to a significant reduction in the total volume $(\mathrm{ml} / \mathrm{kg})$ of blood transfused per infant and in the number of transfusions per infant. Two studies $(n=188)$ reported a significant reduction in the number of donors to whom the infant was exposed. There was a significant increase in the risk of stage $\geq 3$ retinopathy of prematurity (ROP) in the early EPO group [typical RR; $1.65(95 \% \mathrm{Cl} 1.12$,
2.43); 8 studies, 984 infants] (fig. 2). The rates for mortality and other neonatal morbidities were not significantly changed by early EPO treatment nor were neurodevelopmental outcomes at 18-22 months in the small number of infants tested to date.

\section{Reviewers' Conclusions}

Early administration of EPO reduces the use of RBC transfusions and the volume of RBCs transfused. These small reductions are of limited clinical importance. Donor exposure is probably not avoided since most studies included infants who had received RBC transfusions prior to trial entry. There was a significant increase in the rate of ROP (stage 3 or greater). Early EPO does not significantly decrease or increase any of the other important adverse outcomes. Ongoing research should deal with the issue of ROP and evaluate the current clinical practice that will limit donor exposure. Due to the limited benefits and the increased risk of ROP, early administration of EPO is not recommended. Evidence is lacking for the possible neuroprotective role of EPO in preterm infants.

Ohlsson A, Aher SM: Early erythropoietin for preventing red blood cell transfusion in preterm and/or low birth weight infants. Cochrane Database of Systematic Reviews 2006, Issue 3. Art. No.: CD004863. DOI: 10.1002/14651858.CD004863.pub2.

\section{KARGER}

Fax +41613061234 E-Mail karger@karger.ch www.karger.com
(C) 2012 S. Karger AG, Base

$1661-7800 / 12 / 1022-0127 \$ 38.00 / 0$ 


\section{Commentary}

Roger F. Soll, Burlington, Vt.

In newborn infants, the number of red blood cells in the circulation decreases after birth. In infants born before term, this decrease is exaggerated by frequent withdrawal of blood, which may be necessary to monitor the infant's clinical condition. Therefore, infants born before term are likely to require transfusions of red blood cells.

Erythropoietin (EPO) is the hormone that regulates and stimulates red blood cell production. Plasma levels of EPO are low in preterm infants, providing a rationale for the use of EPO to prevent or treat anemia [1-4].

Drs Ohlsson and Aher report a systematic review of the use of early EPO (before the infant reaches 8 days of life) for preventing red blood cell transfusions in preterm and/or low birth weight infants. The meta-analysis includes 27 studies enrolling over 2,000 infants. Early EPO reduces the risk of the use of one or more blood transfusions (fig. 1). However, the authors note that there is a significant increase in the risk of stage 3 or greater retinopathy of prematurity in the early EPO group (fig. 2).

EPO remains a mainstay of treatment in many units. In a large network database, Clark et al. [5] estimate that 50 infants are exposed to EPO per 1,000 NICU discharged patients (a rate similar to the exposure rate of indomethacin or dexamethasone). Yet the benefits of EPO (decreased transfusion) are limited. In an editorial debating the benefits of EPO versus erythrocyte transfusion, Von Kohorn and Ehrenkranz [6] note that approaches to care, such as restrictive transfusion criteria or other efforts to limit donor exposure, minimize the benefit of EPO therapy. Although retinopathy of prematurity was not the primary outcome of any of the studies, the increase in severe ROP is of great concern. It calls into question the routine use of EPO to prevent transfusion and makes the future trials of EPO for infants with hypoxic ischemic encephalopathy particularly problematic when this includes treatment of a preterm population at risk for ROP.

\section{Acknowledgment}

Editorial support of the Cochrane Neonatal Review Group has been funded with Federal Funds from the Eunice Kennedy Shriver National Institute of Child Health and Human Development, National Institutes of Health, Department of Health, USA, under Contract No. HHSN2752011000016C.

\section{References}

1 Romagnoli C, Tesfagabir MG, Giannantonio C, Papacci P: Erythropoietin and retinopathy of prematurity. Early Hum Dev 2011;87(suppl 1):S39-S42.

2 Suk KK, Dunbar JA, Liu A, Daher NS, Leng CK, Leng JK, Lim P, Weller S, Fayard E: Human recombinant erythropoietin and the incidence of retinopathy of prematurity: a multiple regression model. J AAPOS 2008; 12:233-238.

3 McPherson RJ, Juul SE: Erythropoietin for infants with hypoxic-ischemic encephalopathy. Curr Opin Pediatr 2010;22:139-145.

4 Bishara N, Ohls RK: Current controversies in the management of the anemia of prematurity. Semin Perinatol 2009;33:29-34.

5 Clark RH, Bloom BT, Spitzer AR, Gerstmann DR: Reported medication use in the neonatal intensive care unit: data from a large national data set. Pediatrics 2006;117:1979-1987.

6 Von Kohorn I, Ehrenkranz RA: Anemia in the preterm infant: erythropoietin versus erythrocyte transfusion - it's not that simple. Clin Perinatol 2009;36:111-123. 


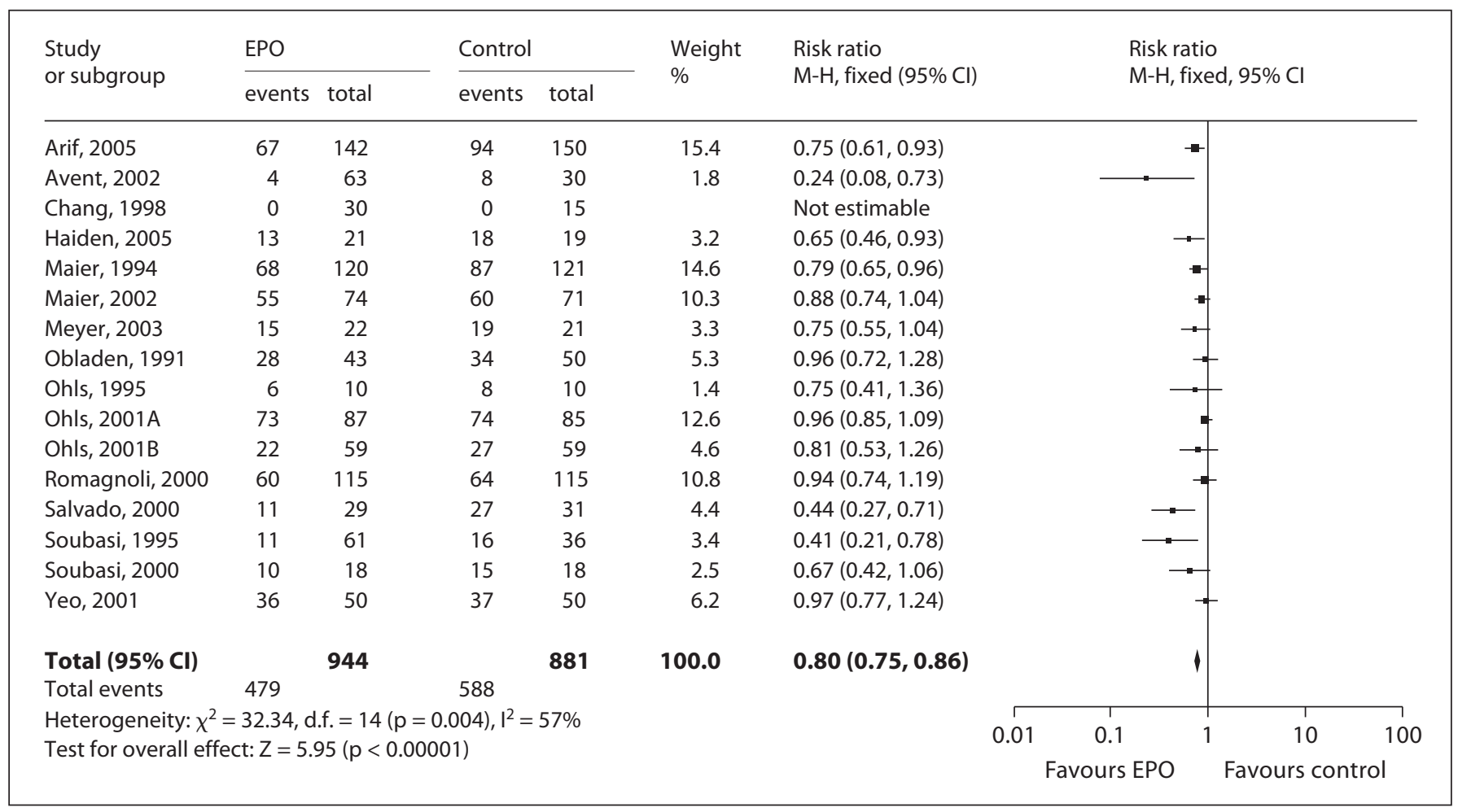

Fig. 1. Effect of EPO versus placebo or no treatment on the use of one or more red blood cell transfusions.

\begin{tabular}{|c|c|c|c|c|c|c|c|c|c|}
\hline \multirow{3}{*}{$\begin{array}{l}\begin{array}{l}\text { Study } \\
\text { or subgroup }\end{array} \\
\text { Bierer, } 2006\end{array}$} & \multicolumn{2}{|c|}{ Treatment } & \multicolumn{2}{|l|}{ Control } & \multirow{3}{*}{$\begin{array}{l}\begin{array}{l}\text { Weight } \\
\%\end{array} \\
5.1\end{array}$} & \multirow{2}{*}{$\begin{array}{l}\text { Risk ratio } \\
\mathrm{M}-\mathrm{H} \text {, fixed }(95 \% \mathrm{Cl})\end{array}$} & \multirow{2}{*}{\multicolumn{2}{|c|}{$\begin{array}{l}\text { Risk ratio } \\
\mathrm{M}-\mathrm{H} \text {, fixed, } 95 \% \mathrm{Cl}\end{array}$}} & \\
\hline & \multirow{2}{*}{$\frac{\text { events }}{1}$} & \multirow{2}{*}{$\begin{array}{r}\text { total } \\
7\end{array}$} & \multirow{2}{*}{$\frac{\text { events }}{2}$} & \multirow{2}{*}{$\frac{\text { total }}{8}$} & & & & & \\
\hline & & & & & & $0.57(0.06,5.03)$ & $\longrightarrow$ & - & \\
\hline Fauchère, 2008 & 1 & 24 & 0 & 15 & 1.7 & $1.92(0.08,44.29)$ & & & \\
\hline Haiden, 2005 & 1 & 21 & 0 & 19 & 1.4 & $2.73(0.12,63.19)$ & & & \\
\hline Maier, 1994 & 1 & 120 & 1 & 121 & 2.7 & $1.01(0.06,15.94)$ & & & \\
\hline Maier, 2002 & 12 & 67 & 5 & 62 & 14.3 & $2.22(0.83,5.94)$ & & 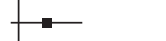 & \\
\hline Ohls, 2001A & 17 & 87 & 14 & 85 & 39.0 & $1.19(0.62,2.25)$ & & - & \\
\hline Ohls, 2001B & 7 & 59 & 4 & 59 & 11.0 & $1.75(0.54,5.66)$ & & - & \\
\hline Romagnoli, 2000 & 20 & 115 & 9 & 115 & 24.8 & $2.22(1.06,4.67)$ & & $\rightarrow-$ & \\
\hline Total $(95 \% \mathrm{Cl})$ & & 500 & & 484 & 100.0 & $1.65(1.12,2.43)$ & & $\gamma$ & \\
\hline Total events & 60 & & 35 & & & & & & \\
\hline Heterogeneity: $\chi^{2}$ & $=3.14$, d.f & $=7(p$ & ), $I^{2}=0 \%$ & & & 0.001 & 0.1 & 10 & 1,000 \\
\hline Test for overall effe & $\mathrm{ct}: \mathrm{Z}=2$. & $54(p=$ & & & & & $S$ EPO & Favours cc & rol \\
\hline
\end{tabular}

Fig. 2. Effect of EPO versus placebo or no treatment on severe retinopathy of prematurity (stage 3 or greater). 